\title{
Urban Expansion and Agricultural Land Loss in China: A Multiscale Perspective
}

\author{
Kaifang Shi ${ }^{1,2}$, Yun Chen ${ }^{2, *}$, Bailang Yu ${ }^{1, *}$, Tingbao Xu ${ }^{3}$, Linyi Li ${ }^{4}$, Chang Huang ${ }^{5}$, Rui Liu ${ }^{1}$, \\ Zuoqi Chen ${ }^{1}$ and Jianping $\mathrm{Wu}^{1}$
}

1 Key Laboratory of Geographic Information Science, Ministry of Education, East China Normal University, Shanghai 200241, China; shikf1986@126.com (K.S.); drruiliu@yeah.net (R.L.); zuoqi.chen@gmail.com (Z.C.); jpwu@geo.ecnu.edu.cn (J.W.)

2 CSIRO Land and Water, Canberra 2601, Australia

3 Fenner School of Environment and Society, The Australian National University, Linnaeus Way, Canberra 2601, Australia; Tingbao.Xu@anu.edu.au

4 School of Remote Sensing and Information Engineering, Wuhan University, Wuhan 430079, China; lilinyi@whu.edu.cn

5 College of Urban and Environmental Sciences, Northwest University, Xi'an 710127, China; changh@nwu.edu.cn

* Correspondence: Yun.Chen@csiro.au (Y.C.); blyu@geo.ecnu.edu.cn (B.Y.); Tel.: +61-2-6246-5729 (Y.C.); +86-21-5434-1172 (B.Y.)

Academic Editor: Marc A. Rosen

Received: 25 May 2016; Accepted: 8 August 2016; Published: 11 August 2016

\begin{abstract}
China's rapid urbanization has contributed to a massive agricultural land loss that could threaten its food security. Timely and accurate mapping of urban expansion and urbanization-related agricultural land loss can provide viable measures to be taken for urban planning and agricultural land protection. In this study, urban expansion in China from 2001 to 2013 was mapped using the nighttime stable light (NSL), normalized difference vegetation index (NDVI), and water body data. Urbanization-related agricultural land loss during this time period was then evaluated at national, regional, and metropolitan scales by integrating multiple sources of geographic data. The results revealed that China's total urban area increased from 31,076 km² in 2001 to $80,887 \mathrm{~km}^{2}$ in 2013, with an average annual growth rate of $13.36 \%$. This widespread urban expansion consumed $33,080 \mathrm{~km}^{2}$ of agricultural land during this period. At a regional scale, the eastern region lost $18,542 \mathrm{~km}^{2}$ or $1.2 \%$ of its total agricultural land area. At a metropolitan scale, the Shanghai-Nanjing-Hangzhou (SNH) and Pearl River Delta (PRD) areas underwent high levels of agricultural land loss with a decrease of $6.12 \%\left(4728 \mathrm{~km}^{2}\right)$ and $6.05 \%\left(2702 \mathrm{~km}^{2}\right)$ of their total agricultural land areas, respectively. Special attention should be paid to the PRD, with a decline of $13.30 \%\left(1843 \mathrm{~km}^{2}\right)$ of its cropland. Effective policies and strategies should be implemented to mitigate urbanization-related agricultural land loss in the context of China's rapid urbanization.
\end{abstract}

Keywords: urban expansion; agricultural land loss; nighttime light data; China

\section{Introduction}

Agricultural land loss, as a type of land use/cover change (LUCC), is one of the most important factors that affect food security [1-4]. Human activities, especially urbanization, have resulted in a significant loss of agricultural land during the past decades around the world [5-8]. Substantial areas of agricultural land, including cropland, forest, and grassland, have been converted into artificial or impervious surfaces $[3,9,10]$. Therefore, mapping and quantifying agricultural land loss following urban expansion are essential to understanding its impact on food security. 
China has been experiencing unprecedented urban expansion since its "reform and opening up" starting from the late 1970s [11,12]. The urban area in China has increased about four-fold [13]. China's rapid urbanization has contributed to a massive agricultural land loss that could threaten its food security [14]. For example, urbanization in the more developed eastern China led to a loss of $7 \%$ from 1995 to 2000 [15]. In addition, the expansion of urban area has reduced agricultural land by $34 \%$ in some major cities of the Beijing-Tianjin-Hebei region in China from 1990 to 2000 [16]. Approximately $24 \%$ of agricultural land was converted to urban land in Changzhou, Jiangsu province, China from 2004 to 2011 [17]. Hence, the study of agricultural land loss due to urbanization is particularly crucial in China.

Previous studies have estimated agricultural land loss caused by urban expansion in two major ways. Firstly, socioeconomic statistical data based on administrative units were used to obtain information on loss $[15,18]$. In spite of their authoritativeness, the socioeconomic statistical data only provide numeric records of loss for an entire administrative unit without showing internal spatial patterns [6]. Secondly, medium to high spatial resolution remotely sensed images have been widely employed for loss estimation $[6,16,19]$. These data mainly include Landsat Thematic Mapper (TM)/Operational Land Imager and Thermal Infrared Sensor (OLI-TIRS) images [20,21]. However, since they are limited by their geographic coverage [22,23], large amounts of computation and labor are required to obtain one-time information on loss at a national scale. As a consequence, few studies have accurately mapped urbanization-related agricultural land loss in a timely manner, especially at the national scale.

To deal with the above existing issues, this study aims to map urban expansion and agricultural land loss in China from 2001 to 2013. The objectives are (1) to map urban expansion at $1 \mathrm{~km}$ resolution in China using the nighttime stable light (NSL), normalized difference vegetation index (NDVI), and water body data; (2) to monitor urbanization-related agricultural land loss at $1 \mathrm{~km}$ resolution in China using the above geographic data and land use/cover data; (3) to analyze urbanization-related agricultural land loss from national scale to regional and metropolitan scales.

The remainder of this study is organized as follows. Section 2 describes the study areas and data source. Section 3 introduces the methodology used. Section 4 analyzes the results of urban expansion and agriculture land loss. Section 5 presents the discussion, and the conclusions are given in Section 6 .

\section{Study Areas and Data Sources}

\subsection{Study Areas}

Study areas were selected from three different levels for multiple-scales analysis. Following the first national level, the second is the regional level. Due to China's uneven socioeconomic development, different regions with great disparities of urban expansion have been formed. In this study, China was divided into three regions (eastern, central, and western) based on their socioeconomic development and geographical position (Figure 1). It is noted that these divided regions have been commonly accepted and widely used to analyze China's socioeconomic development $[24,25]$. The metropolitan scale forms the third level. Because China's urban expansion is concentrated in some metropolitan areas which contribute the most to agricultural land loss [16], six typical metropolitan areas-Shanghai-Nanjing-Hangzhou (SNH), Beijing-Tianjin-Tangshan (BTT), Pearl River Delta (PRD), Chengdu-Deyang-Mianyang (CDM), Zhengzhou-Luoyang-Jiaozuo (ZLJ), and Wuhan-Ezhou-Huangshi (WEH) (Figure 1)—were selected to represent this level. 


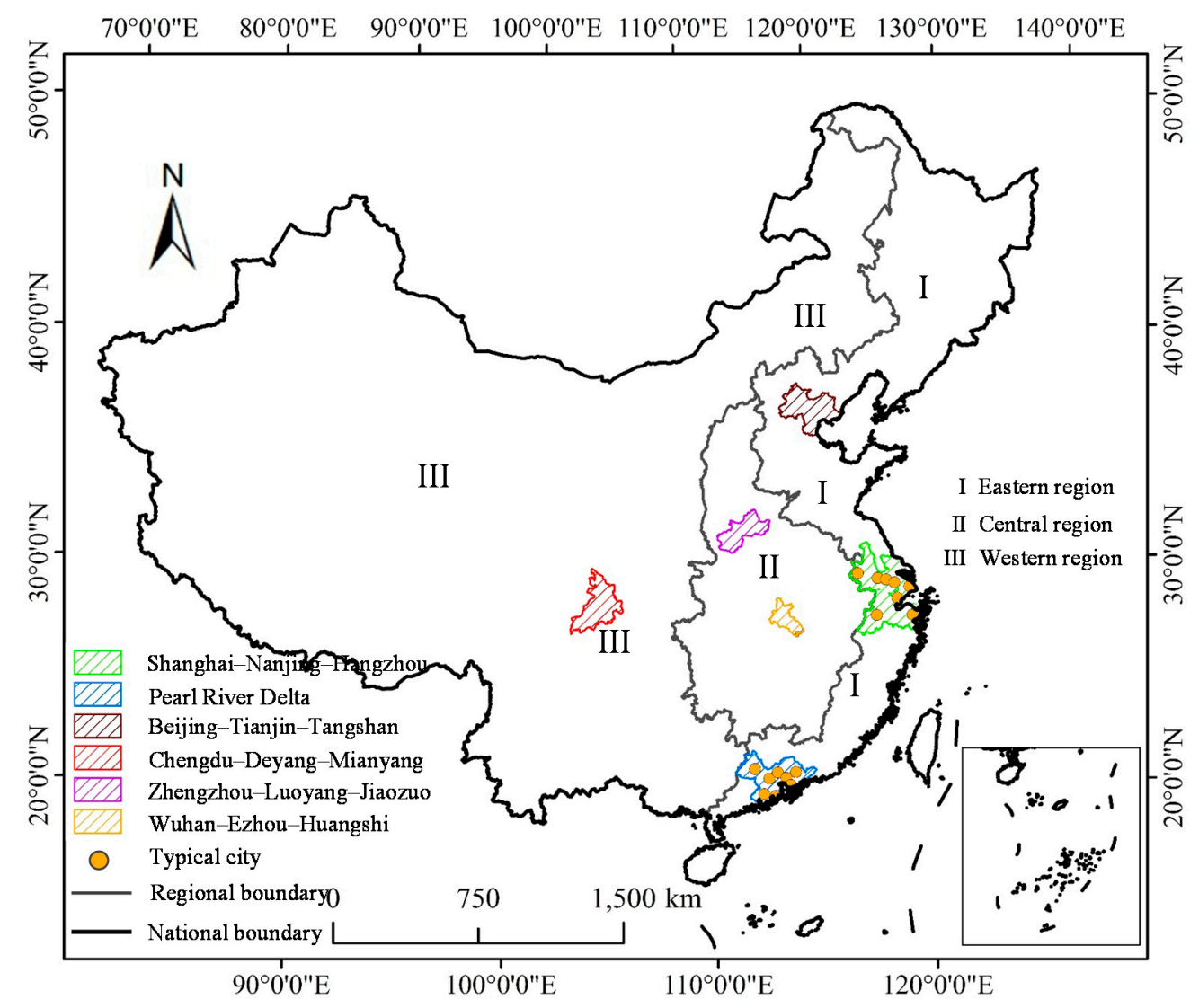

Figure 1. The location of study areas.

\subsection{Data Source}

The Defense Meteorological Satellite Program's Operational Linescan System (DMSP-OLS) NSL data were obtained from the National Oceanic and Atmospheric Administration (NOAA)/National Geophysical Data Center (NGDC). These data include the lights from cities, towns, and other sites with persistent lighting and removed ephemeral events, such as fire, and present the annual average brightness in units of six-bit digital numbers (DN) ranging from 0 to 63 . They cover an area of -180 to 180 degrees in longitude and -65 to 75 degrees in latitude, at a spatial resolution of 30 arc-seconds (about $1 \mathrm{~km}$ ). Since the NSL data were collected by three different DMSP satellites (F15, F16, and F18), they could not be directly used to map urban expansion due to the lack of continuity and comparability [26-29]. In this study, we assumed that the NSL data would continuously grow in China, and the DN values in an earlier year would be equal to or smaller than those in a later year. Spatial data were converted into raster format and resampled to a spatial resolution of $1 \mathrm{~km}$ and projected into the Lambert Azimuthal Equal Area Projection with reference to WGS84 datum.

The Moderate Resolution Imaging Spectroradiometer (MODIS) monthly NDVI and water body data were also used to map urban expansion. The national land cover/use (NLC) data were used to estimate urbanization-related agricultural land loss in China. Landsat TM/OLI-TIRS images and provincial gross domestic product (GDP) were applied to assess the accuracy of urban area extraction. The statistical data on grain production were employed to quantify the impact of urbanization-related agricultural land loss at a local scale. A summary of the data used in this study is given in Table 1. 
Table 1. Description of the data used in this study.

\begin{tabular}{|c|c|c|c|}
\hline Data & Data Description & Year & Source \\
\hline NSL & $\begin{array}{l}\text { Global nighttime stable light } \\
\text { composite data }\end{array}$ & $\begin{array}{l}\text { 2001, 2005, 2009, } \\
\text { and } 2013\end{array}$ & $\begin{array}{c}\text { NOAA/NGDC } \\
\text { (http://www.ngdc.noaa.gov/eog/dmsp.html) }\end{array}$ \\
\hline MODIS-NDVI & $\begin{array}{c}\text { Monthly NDVI composite } \\
\text { data of China at } \\
1 \mathrm{~km} \text { resolution }\end{array}$ & $\begin{array}{l}2001,2005,2009 \\
\text { and } 2010\end{array}$ & $\begin{array}{l}\text { Geospatial Data Cloud } \\
\text { (http://www.gscloud.cn) }\end{array}$ \\
\hline Water body & Shapefile of water in China & 2013 & ESRI Baruch Geoportal \\
\hline TM/OLI-TIRS & $\begin{array}{l}\text { Ten images covering six } \\
\text { cities (Beijing, Tianjin, } \\
\text { Shanghai, Chengdu, Wuhan } \\
\text { and Hefei) at } 30 \mathrm{~m} \text { resolution }\end{array}$ & 2001 and 2013 & $\begin{array}{l}\text { Geospatial Data Cloud } \\
\text { (http://www.gscloud.cn) }\end{array}$ \\
\hline NLC & $\begin{array}{l}\text { National land cover/use } \\
\text { data at } 1 \mathrm{~km} \text { resolution } \\
\text { in China }\end{array}$ & 2000 & $\begin{array}{l}\text { National Data Sharing Infrastructure of Earth } \\
\text { System Science } \\
\text { (http://www2.geodata.cn/index.html) }\end{array}$ \\
\hline $\begin{array}{l}\text { Socioeconomic } \\
\text { census data }\end{array}$ & $\begin{array}{l}\text { Annual statistical data of } \\
\text { two types-GDP }\left(10^{8} \text { Yuan }\right) \\
\text { and grain production }\left(10^{4} \mathrm{t}\right) \\
\text { in China }\end{array}$ & $\begin{array}{l}\text { 2001, 2005, 2009, } \\
\text { and } 2013\end{array}$ & $\begin{array}{l}\text { The Statistical Database of Economic and Social } \\
\text { Development by the National Knowledge } \\
\text { Infrastructure of China } \\
\text { (http://tongji.cnki.net) }\end{array}$ \\
\hline $\begin{array}{l}\text { Administrative } \\
\text { boundaries }\end{array}$ & $\begin{array}{l}\text { Shape files of provinces, } \\
\text { cities in China }\end{array}$ & 2008 & $\begin{array}{l}\text { National Geomatics Center of China } \\
\text { (http://ngcc.sbsm.gov.cn/article/en/or/an/) }\end{array}$ \\
\hline
\end{tabular}

\section{Methodology}

Three main procedures were undertaken to map agricultural land loss caused by urban expansion in China: urban expansion was extracted from 2001 to 2013; agricultural land was mapped in 2000; and agricultural land loss caused by urban expansion was estimated at national, regional, and urban metropolitan scales (Figure 2).

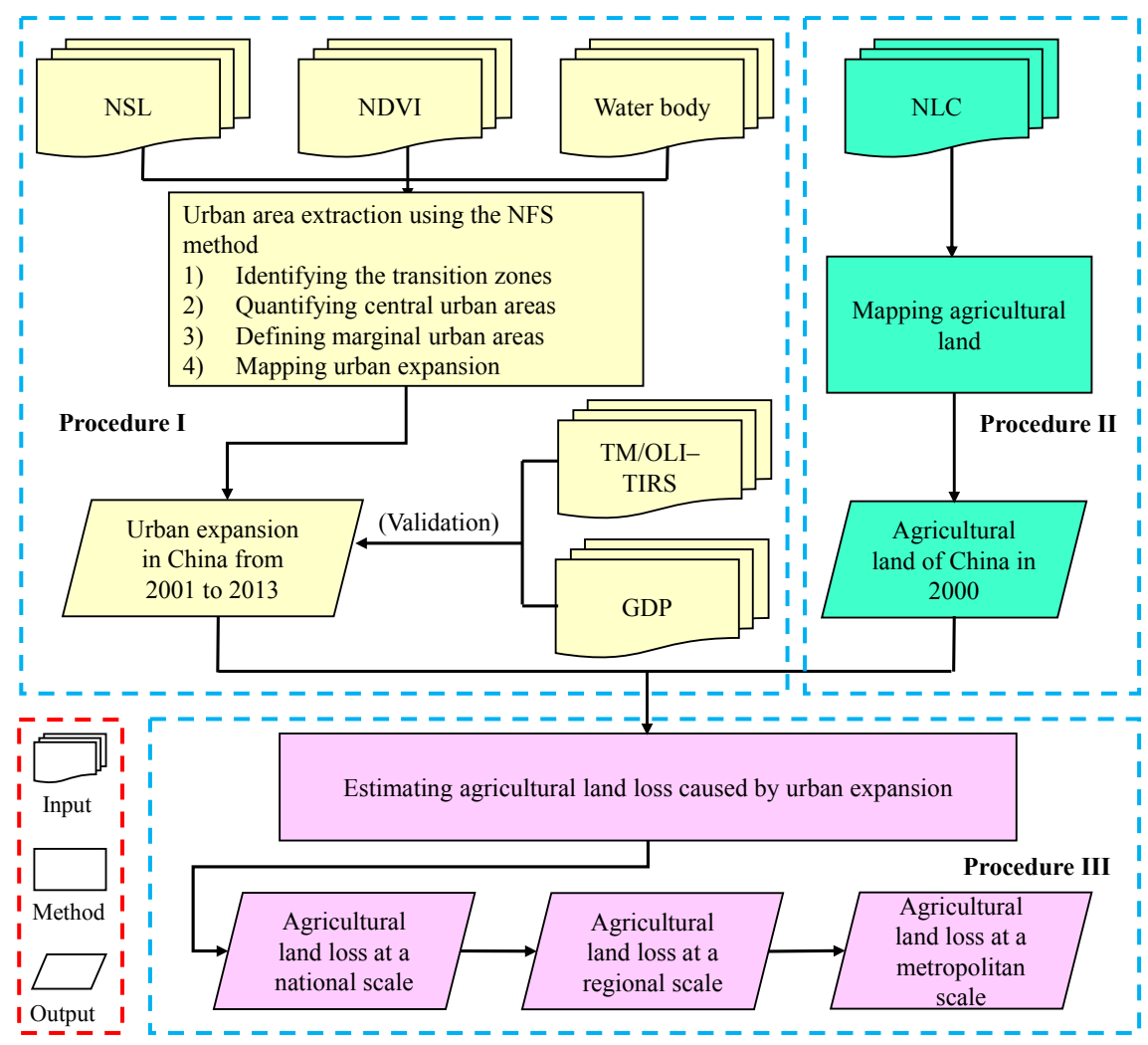

Figure 2. Flowchart of methodology. 


\subsection{Extracting Urban Expansion}

Accurately extracting urban expansion is a prerequisite for quantifying agricultural land loss caused by urbanization. The NSL data have been demonstrated as an accurate and valuable data source for mapping urban expansion at regional, national, continental, and global scales [30-34] due to their appropriate temporal and spatial resolution. Among the published methods for urban area extraction from NSL data, the neighborhood focal statistic (NFS) method has been effectively used due to its simplicity $[35,36]$. However, due to the "blooming" natural features in the NSL data, the NFS method might confuse some non-urban pixels located in the marginal urban areas, and misclassify many natural features situated within urban regions. In order to improve the accuracy of urban extraction, we mapped urban expansion in China by applying the NFS method to the NSL, NDVI, and water body data from 2001 to 2013. The specific steps for urban extraction are as follows:

(1) Identifying the transition zones. Because the NSL data could be treated as Digital Elevation Model (DEM) images, identifying the dividing lines between ridges and valleys is equivalent to distinguishing urban and non-urban areas. However, due to the "blooming effect" of the NSL data, these lines are actually transition zones, including both urban and non-urban areas. In this study, the transition zones were identified by using maximum and minimum NFS calculations.

(2) Quantifying central urban areas. According to the differences of pixel values in the NSL data, the regions with relatively high values on the side of transition zones were classified as central urban areas.

(3) Defining marginal urban areas. Since the transition zones are more heterogeneous landscapes, the marginal urban areas hidden in the transition zones were extracted using the minimum NFS calculation.

(4) Mapping urban expansion. The primary urban maps were obtained by overlaying central and marginal urban areas. To deal with any misclassifications in these primary urban maps, we applied NDVI and water body data to remove natural features located within urban areas from the primary urban maps. Moreover, urban areas were assumed to continuously grow outward, and an urban pixel of reclassified urban maps in an earlier year would remain as urban in a later year. Additional information can be found in the supplementary materials.

Two methods were used to validate the mapping of urban area estimation from the NSL, NDVI, and water body data. Since Yang et al. [37] and He et al. [13] demonstrated that GDP correlated well with urban expansion, we firstly evaluated the estimated results against GDP at the provincial level in China. Secondly, Landsat TM/OLI-TIRS images were employed to validate the spatial accuracy of urban areas. Considering Landsat TM/OLI-TIRS images have much higher spatial resolution $(30 \mathrm{~m})$ than the NSL data $(1 \mathrm{~km})$, they are efficient to represent the real pattern of urban areas $[20,30,38,39]$. The urban areas extracted from Landsat TM/OLI-TIRS images were produced by the maximum likelihood classifiers based on training data extracted from typical urban areas. These results at $30 \mathrm{~m}$ resolution were then aggregated to $1 \mathrm{~km}$ urban maps to facilitate the intercomparison [20]. Finally, the Kappa, overall accuracy (OA), commission error (CE), and omission error (OE) were calculated and used for the accuracy estimation.

\subsection{Mapping Agricultural Land in 2000}

The land use/cover classification scheme (2006-2020) developed by the Outline of the National Overall Planning on Land Use [40] was adopted in this study and employed to extract agricultural land from the 2000 NLC data. According to this classification scheme, any farmland, including cropland, grassland, and forest, can be regarded as agricultural land. Several land cover types in the 2000 NLC data were combined to map three agricultural land classes-cropland, grassland, and forest. Specifically, paddy and dry land were merged into cropland; forest, shrub wood, open and other forest were reclassified as forest; dense, moderate, and sparse grass were all considered as grass 
cover in this study. The detailed descriptions of each land use/cover type in the NLC data can be found in Ran et al. [41].

\subsection{Estimating Agricultural Land Loss Caused by Urban Expansion}

Agricultural land loss from urban expansion refers to the conversion of the corresponding land cover into urban land use. In this study, we calculated the areas of agricultural land loss in the urban expansion process for each pixel using Formula (1):

$$
A L_{(i, j)}=A O_{(i, j)}^{2000} \times\left(\operatorname{Urban}_{i}^{2013}-\operatorname{Urban}_{i}^{2001}\right),
$$

where $A L_{(i, j)}$ is the area of $j$ type agricultural land lost at the $i$ th pixel from 2001 to 2013; $A O_{(i, j)}$ represents the area of $j$ type agricultural land at the $i$ th pixel in 2000. Urban ${ }_{i}{ }^{2013}$ and $\operatorname{Urban}_{i}{ }^{2001}$ are class values at the $i$ th pixel in the urban land map in 2001 and 2013, respectively. The class value of 1 represents urban while 0 is non-urban. The total area of agricultural land loss in each pixel was calculated through summation as presented in Formula (2):

$$
A L_{i}=\sum_{j=1}^{m} A L_{(i, j)}
$$

where $A L_{i}$ is the total area of agricultural land loss within the $i$ th pixel from 2001 to 2013; $m$ represents the original number of agricultural land types in 2000.

\section{Results}

\subsection{Validation of Urban Area Extraction}

The regression model was firstly used to compare GDP against the mapped urban areas at the provincial level in China. Based on current data availability, 31 provinces were used to implement the assessment. The results showed that the estimated urban expansion had a strong correlation $(R \geqslant 0.75)$ with the GDP growth from 2001 to 2013 at the 0.001 level of significance (Figure 3). Six important capital cities (Beijing, Tianjin, Shanghai, Chengdu, Wuhan, and Hefei) with various levels of urbanization were chosen as samples to validate the spatial accuracy of urban areas. Beijing, Tianjin, and Shanghai are the most developed cities with a large-scale urban expansion in China. Chengdu, Wuhan, and Hefei are the socioeconomic centers in the western (Chengdu) and central (Wuhan and Hefei) regions, respectively. Hence, these cities are the most representative samples for urban expansion validation. The results showed that the urban areas of these cities extracted using the NSL, NDVI, and water body data in 2001 and 2013 presented an average Kappa value of 0.63 , an average OA value of 93.58\%, an average $\mathrm{CE}$ value of $2.67 \%$, and an average OE value of $3.75 \%$ (Figures 4 and 5, Table 2). The relatively high accuracy suggested that the proposed method could be effectively and accurately mapping urban expansion in China.
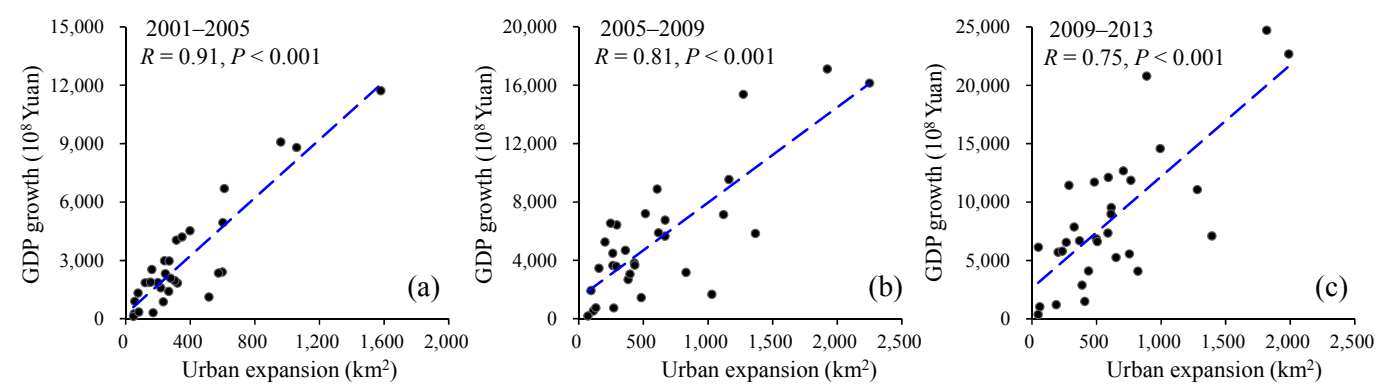

Figure 3. Correlation between urban expansion and GDP growth at the provincial level. (a) 2001-2005; (b) 2005-2009; (c) 2009-2010. 


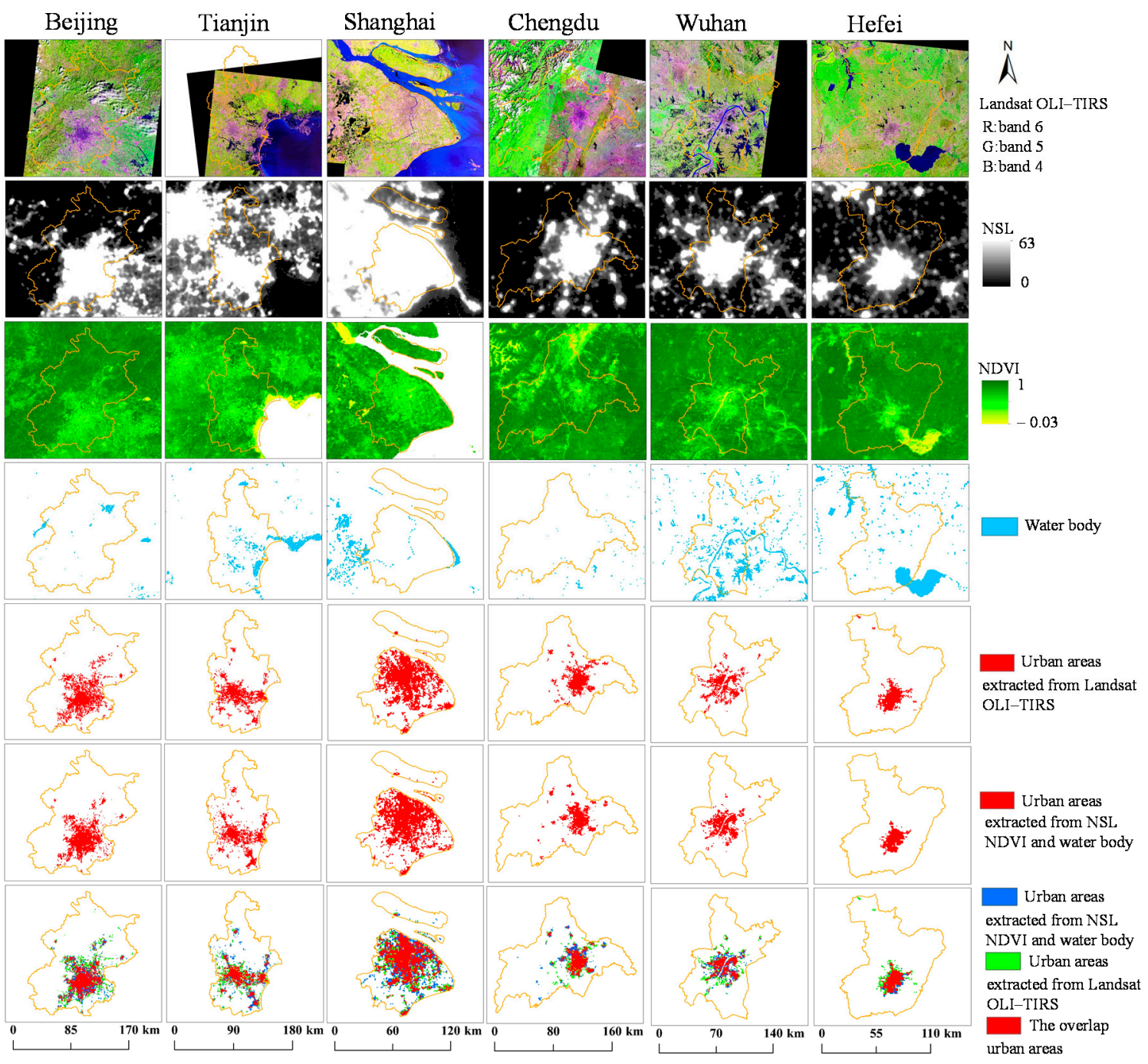

Figure 4. Accuracy assessment of urban areas extracted from the NSL, NDVI, and water body data in comparison with those from Landsat OLI-TIRS images in 2013.

Table 2. Accuracy assessment of urban areas extracted from the NSL, NDVI, and water body data in comparison with those from Landsat TM/OLI-TIRS images.

\begin{tabular}{cccccccc}
\hline Year & Index & Beijing & Tianjin & Shanghai & Chengdu & Wuhan & Hefei \\
\hline \multirow{5}{*}{2001} & Kappa & 0.62 & 0.60 & 0.62 & 0.56 & 0.63 & 0.66 \\
& OA (\%) & 95.22 & 95.34 & 89.78 & 98.51 & 96.73 & 98.75 \\
& CE (\%) & 1.62 & 1.38 & 3.22 & 0.25 & 0.55 & 0.11 \\
& OE (\%) & 3.17 & 3.27 & 7.00 & 1.24 & 2.72 & 1.15 \\
\hline \multirow{5}{*}{2013} & Kappa & 0.61 & 0.62 & 0.62 & 0.67 & 0.65 & 0.74 \\
& OA (\%) & 90.46 & 89.75 & 82.96 & 94.89 & 93.43 & 97.15 \\
& CE (\%) & 5.33 & 4.55 & 9.24 & 2.36 & 2.54 & 0.85 \\
& OE (\%) & 4.21 & 5.70 & 7.80 & 2.75 & 4.02 & 2.00 \\
\hline \multirow{5}{*}{ Average } & Kappa & 0.61 & 0.61 & 0.62 & 0.61 & 0.64 & 0.70 \\
& OA (\%) & 92.84 & 92.55 & 86.37 & 96.70 & 95.08 & 97.95 \\
& CE (\%) & 3.47 & 2.96 & 6.23 & 1.30 & 1.55 & 0.48 \\
& OE (\%) & 3.69 & 4.49 & 7.40 & 2.00 & 3.37 & 1.57 \\
\hline
\end{tabular}




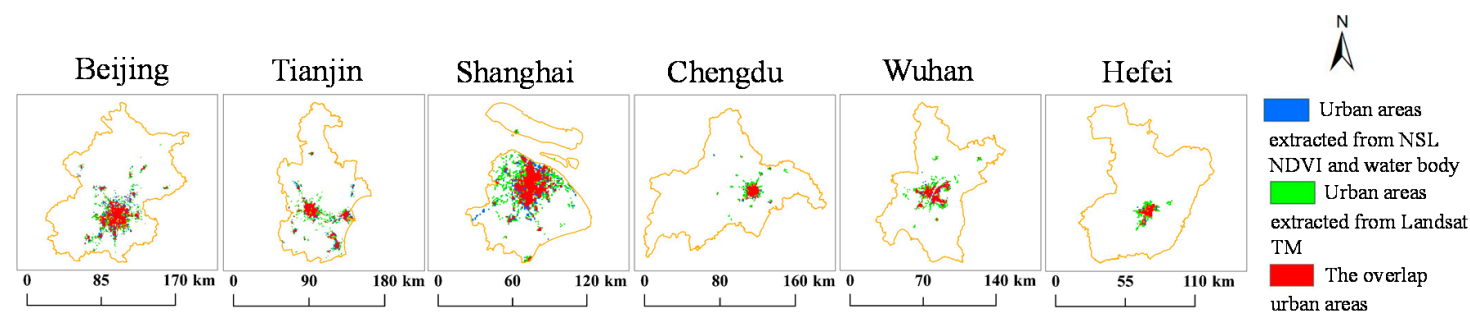

Figure 5. Accuracy assessment of urban areas extracted from the NSL, NDVI, and water body data in comparison with those from Landsat TM images in 2001.

\subsection{Urban Expansion from 2001 to 2013}

The spatial distribution of urban expansion in China from 2001 to 2013 mapped using the NSL, NDVI, and water body data is shown in Figure 6. Over the past decade, China experienced accelerated urban expansion, at a much higher rate than the world average. China's total urban area increased from $31,076 \mathrm{~km}^{2}$ in 2001 to $80,887 \mathrm{~km}^{2}$ in 2013 , with an average annual growth rate of $13.36 \%$, while the world average from 1990 to 2000 was only 3.20\% [42]. Consistent with China's urbanization trend, the urban expansion within the three regions increased continuously from 2001 to 2013 . However, our mapping showed a great difference in urban expansion speed between these regions, with the eastern region having the largest percentage of total land area to become urban areas $\left(1.69 \% ; 28,463 \mathrm{~km}^{2}\right)$, the central region experiencing medium levels of urbanization with a net growth of $0.75 \%\left(7736 \mathrm{~km}^{2}\right)$ of the total land area, while the western region showing the lowest percentage of its total area $\left(0.20 \% ; 13,612 \mathrm{~km}^{2}\right)$ to become urban areas (Table 3).

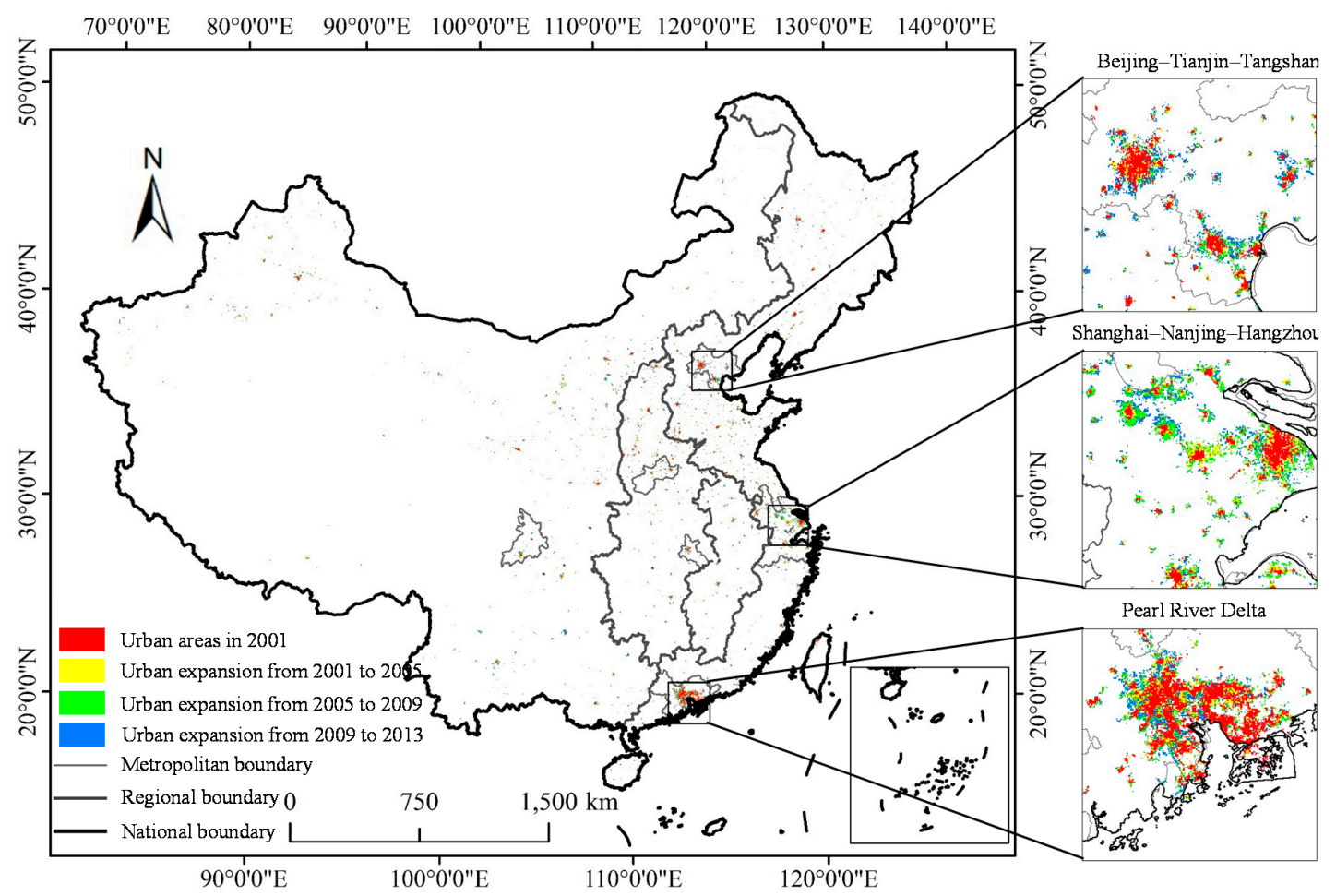

Figure 6. Urban expansion in China from 2001 to 2013.

Six metropolitan areas accounted for $2.88 \%$ of China's total land area but contained $33.21 \%$ of the country's new urbanized areas from 2001 to 2013 (Table 3). The SNH, BTT, and PRD experienced high levels of urbanization with more than $2900 \mathrm{~km}^{2}$ of newly urban areas, accounting for more than $6.5 \%$ of their total land areas. For the CDM, ZLJ and WEH, more than $2 \%$ of their land areas were converted into urban areas from 2001 to 2013 (Table 3). 
Table 3. Urban expansion and agricultural land loss at regional and urban agglomeration scales.

\begin{tabular}{|c|c|c|c|c|c|c|c|}
\hline \multirow{2}{*}{$\begin{array}{l}\text { Administrative } \\
\text { Unit }\end{array}$} & \multirow{2}{*}{$\begin{array}{l}\text { Total Land } \\
\text { Area }\left(\mathrm{km}^{2}\right)\end{array}$} & \multicolumn{2}{|c|}{$\begin{array}{l}\text { Agricultural Land in } \\
\qquad 2000\end{array}$} & \multicolumn{2}{|c|}{$\begin{array}{l}\text { Urban Expansion } \\
\text { from } 2001 \text { to } 2013\end{array}$} & \multicolumn{2}{|c|}{$\begin{array}{l}\text { Agricultural Land Loss } \\
\text { from } 2001 \text { to } 2013\end{array}$} \\
\hline & & $\begin{array}{c}\text { Area } \\
\left(\mathrm{km}^{2}\right)\end{array}$ & $\begin{array}{l}\text { Percentage } \\
(\%)\end{array}$ & $\begin{array}{c}\text { Area } \\
\left(\mathrm{km}^{2}\right)\end{array}$ & $\begin{array}{l}\text { Percentage } \\
(\%)\end{array}$ & $\begin{array}{c}\text { Area } \\
\left(\mathrm{km}^{2}\right)\end{array}$ & $\begin{array}{l}\text { Percentage } \\
(\%)\end{array}$ \\
\hline Eastern region & $1,684,856$ & $1,547,427$ & 91.84 & 28,463 & 1.69 & 18,542 & 1.10 \\
\hline Central region & $1,027,217$ & 951,166 & 92.60 & 7736 & 0.75 & 5276 & 0.51 \\
\hline Western region & $6,725,648$ & $4,574,035$ & 68.01 & 13,612 & 0.20 & 9262 & 0.14 \\
\hline $\mathrm{SNH}$ & 95,097 & 77,261 & 81.24 & 6787 & 7.14 & 4728 & 4.97 \\
\hline BTT & 4048 & 32,718 & 76.00 & 2907 & 6.75 & 1680 & 3.90 \\
\hline PRD & 52,556 & 44,636 & 84.93 & 4387 & 8.35 & 2702 & 5.14 \\
\hline CDM & 39,833 & 38,112 & 95.68 & 939 & 2.36 & 666 & 1.67 \\
\hline ZLJ & 26,759 & 24,177 & 90.35 & 928 & 3.47 & 580 & 2.17 \\
\hline WEH & 14,731 & 11,166 & 75.80 & 592 & 4.02 & 325 & 2.21 \\
\hline
\end{tabular}

\subsection{Agricultural Land in 2000}

The spatial distribution of agricultural land in China is shown in Figure 7. In 2000, agricultural land covered $74.94 \%\left(7,072,628 \mathrm{~km}^{2}\right)$ of the total area, with cropland, forest, and grassland accounting for $19.10 \%\left(1,802,821 \mathrm{~km}^{2}\right), 23.93 \%\left(2,257,876 \mathrm{~km}^{2}\right)$, and $31.91 \%\left(3,011,931 \mathrm{~km}^{2}\right)$ of the total area, respectively. The eastern region had high proportions of cropland and forest: $41.88 \%\left(705,574 \mathrm{~km}^{2}\right)$ and $42.16 \%\left(710,365 \mathrm{~km}^{2}\right)$ of their total area, respectively. Of the total area, cropland and forest made up $41.68 \%\left(428,093 \mathrm{~km}^{2}\right)$ and $42.59 \%\left(437,499 \mathrm{~km}^{2}\right)$ in the central region while grassland covered $41.56 \%\left(2,794,869 \mathrm{~km}^{2}\right)$ in the western region. In addition, six metropolitan areas also had different proportions of agricultural land. In terms of proportions of their total areas, cropland was $54.97 \%$ $\left(14,710 \mathrm{~km}^{2}\right)$ in the ZLJ, $54.25 \%\left(7992 \mathrm{~km}^{2}\right)$ in the WEH and $54 \%\left(21,511 \mathrm{~km}^{2}\right)$ in the CDM. Forest was $56.52 \%\left(29,705 \mathrm{~km}^{2}\right)$ in the PRD. It should be pointed out that grassland in particular accounted for $11.21 \%\left(4465 \mathrm{~km}^{2}\right)$ of total area in the CDM (Figure 8 ).

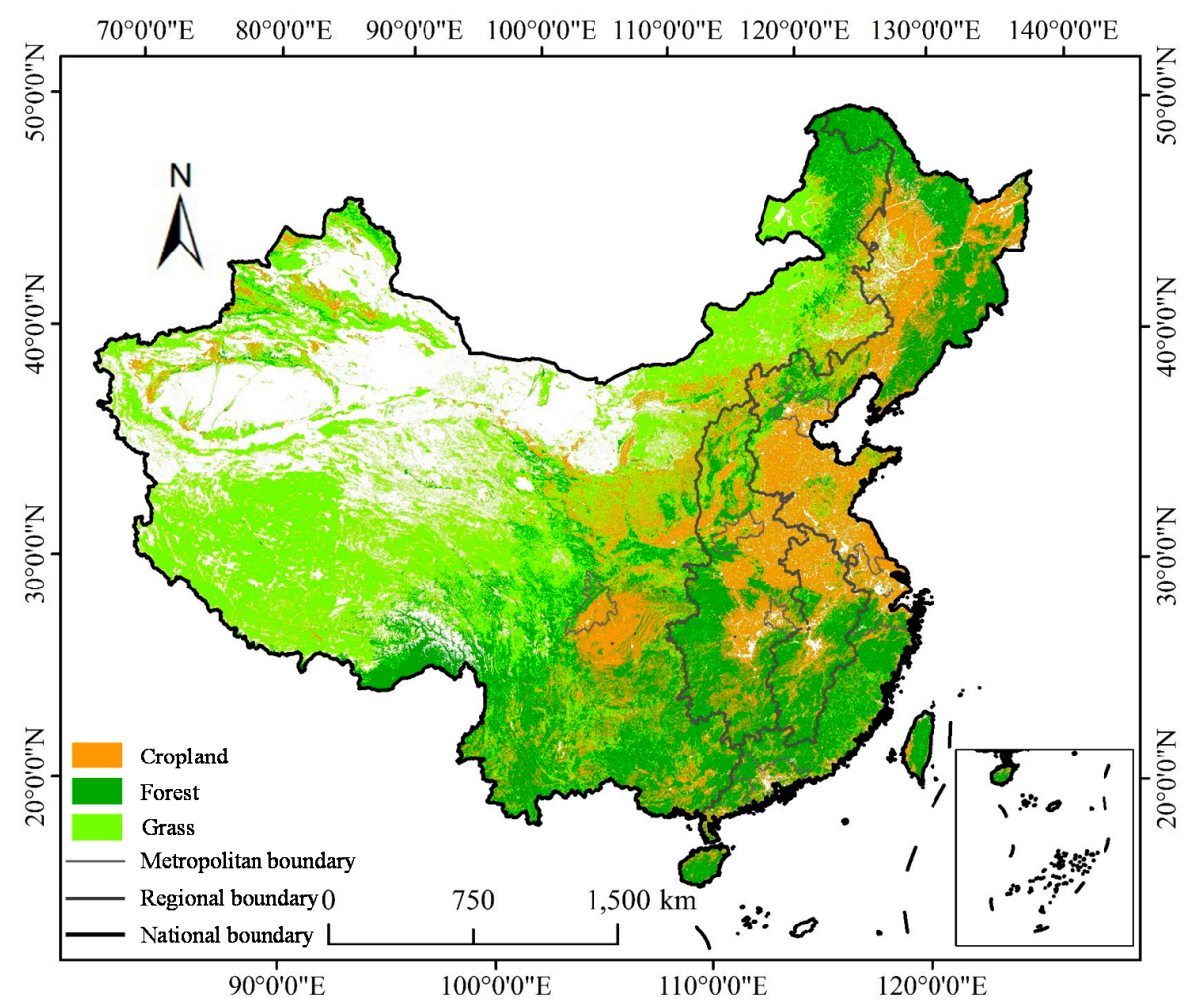

Figure 7. The spatial distribution of agricultural land in China in 2000. 

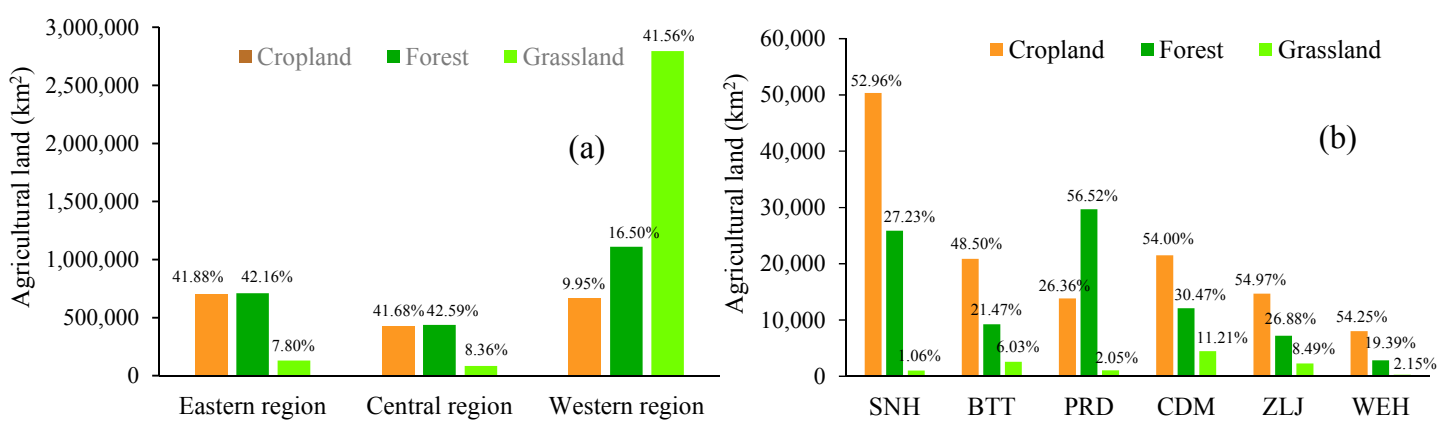

Figure 8. Agricultural land of 2000 at (a) regional and (b) metropolitan scales.

\subsection{Urbanization-Related Agricultural Land Loss from 2001 to 2013 at National, Regional, and Metropolitan Scales}

Widespread urban expansion led to a total loss of agricultural land of $33,080 \mathrm{~km}^{2}$ accounting for $0.47 \%$ of the total area of agricultural land of China in 2000 (Figure 9). Cropland experienced severe loss with a high decline of $24,783 \mathrm{~km}^{2}$ or $1.37 \%$ of the total area of cropland. Forest decreased by a rate of $0.17 \%$ of the total area of forest, which is equal to about $3750 \mathrm{~km}^{2}$ in China. Grassland was least affected, with a low percentage $0.15 \%\left(4547 \mathrm{~km}^{2}\right)$ of its total area being lost to urban expansion.

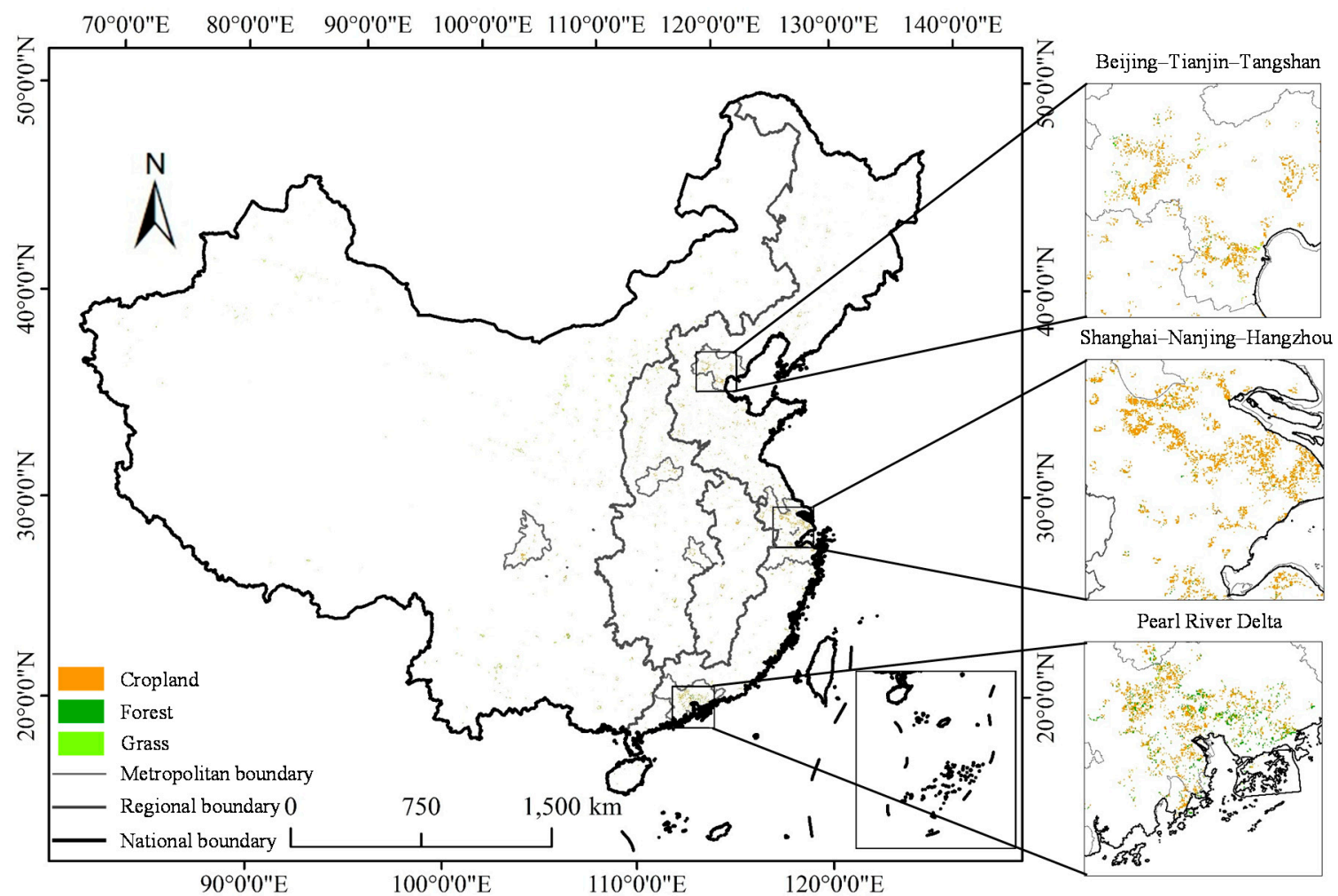

Figure 9. Spatial distribution of urbanization-related agricultural land loss in China from 2001 to 2013.

The impact of urbanization on the area of agricultural land differed in the three regions (Figure 9). The eastern region lost $18,542 \mathrm{~km}^{2}$ or $1.2 \%$ of its total agricultural land area, whereas the central region lost $5276 \mathrm{~km}^{2}(0.55 \%)$, and the western region lost $9262 \mathrm{~km}^{2}(0.20 \%)$. Specifically, the eastern region experienced severe cropland losses with more than $15,000 \mathrm{~km}^{2}$ accounting for $2.24 \%$ of its total cropland area. Although less severe, the central and western regions also lost a considerable proportion $(0.7 \%-1 \%)$ of their cropland during the study period. A relatively significant forest loss also occurred in the eastern region $\left(0.31 \% ; 2180 \mathrm{~km}^{2}\right)$. The central and western region had low levels 
of forest loss, accounting for $0 \%-0.15 \%$ of their total forest areas. Additionally, grassland loss was concentrated in the central region, which accounted for $0.49 \%\left(420 \mathrm{~km}^{2}\right)$ of the total area of grassland. Contrarily, less than $1.5 \%\left(3561 \mathrm{~km}^{2}\right)$ of grassland loss occurred in the western region (Figure 10).
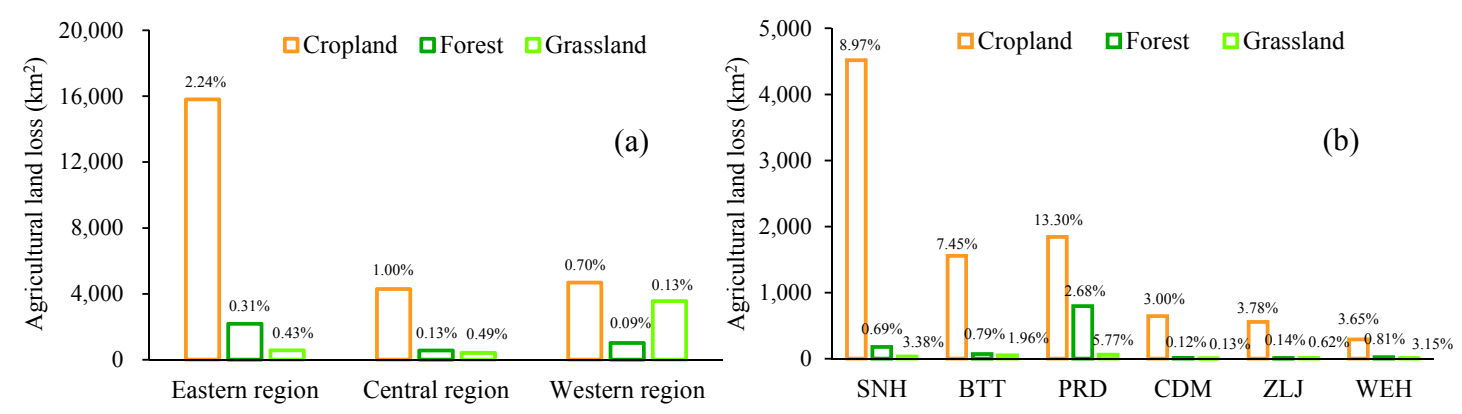

Figure 10. Agricultural land loss following urban expansion from 2001 to 2013 at (a) regional and (b) urban metropolitan scales.

A significant loss of agricultural land has been driven by urban expansion in the six metropolitan areas. Around 10,681 km² of agricultural land was converted into urban land use from 2001 to 2013 in these metropolitan areas. The metropolitan areas with the largest percentages of their total agricultural land areas that have been urbanized were in the SNH $\left(6.12 \% ; 4728 \mathrm{~km}^{2}\right), \operatorname{PRD}\left(6.05 \% ; 2702 \mathrm{~km}^{2}\right)$, and BTT $\left(5.13 \% ; 1680 \mathrm{~km}^{2}\right)$. The WEH and ZLJ underwent medium levels of agricultural land loss with a decrease of $2.91 \%\left(325 \mathrm{~km}^{2}\right)$ and $2.40 \%\left(580 \mathrm{~km}^{2}\right)$ of the total agricultural land area, respectively. In addition, agricultural land loss of $1.75 \%\left(666 \mathrm{~km}^{2}\right)$ was detected in the CDM. It should be noted that a significant percentage ( $>8.5 \%$ ) of cropland was lost in the SNH and PRD. Special attention should be also paid to the PRD, where about $6 \%$ of grassland was lost (Figure 10).

\section{Discussion}

\subsection{Correlation between Urbanization-Related Agricultural Land Loss and Grain Production Decrease}

During the rapid urban expansion of the last decade, considerable urbanization-related agricultural land loss has been found in China, especially in the six metropolitan areas. The SNH and PRD were particularly notable for having experienced an alarming drop in agricultural land coverage; more than $8 \%$ of cropland in these areas was converted into urban land use. The evaluated results were reliable because they were similar to those in Tan et al. [16] and Liang et al. [17]. In addition, compared with other studies [43-45], we also found the urbanization-related agricultural land loss in China to be much more serious than that of other countries.

Normally, there is a positive correlation between agricultural land loss and grain production decrease [46]. However, due to the technological progress and heavy use of chemical fertilizer and pesticides, China's grain production presented a growth trend during the past decades [47-49]. Nevertheless, the significant urbanization-related agricultural land loss has a positive correlation with grain production decrease and partly threatens food security in some developed areas. Figure 11 presents the relationship between urbanization-related agricultural land loss and grain production decrease in 16 typical cities (Figure 1) within the SNH and PRD, showing a positive correlation with $R$-value of 0.65 . Specifically, the substantial area $\left(>500 \mathrm{~km}^{2}\right)$ of agricultural land lost in Shanghai, Guangzhou, Suzhou, Ningbo, Foshan, and Wuxi correlated to a decrease of 2.01 million ton of grain production. Moreover, there was a significant heterogeneity in the quantity and quality of agricultural land with each city, and therefore each city has been experienced different grain production decrease. However, even relatively small agricultural land loss could cause a disproportionate grain production decrease. For example, Zhaoqing had a low level of agricultural land loss $\left(137 \mathrm{~km}^{2}\right)$, yet showed a 0.23 million ton grain production decrease during the study period (Figure 11). Hence, it is very important to implement viable urban planning and agricultural land protection policies in these cities. 

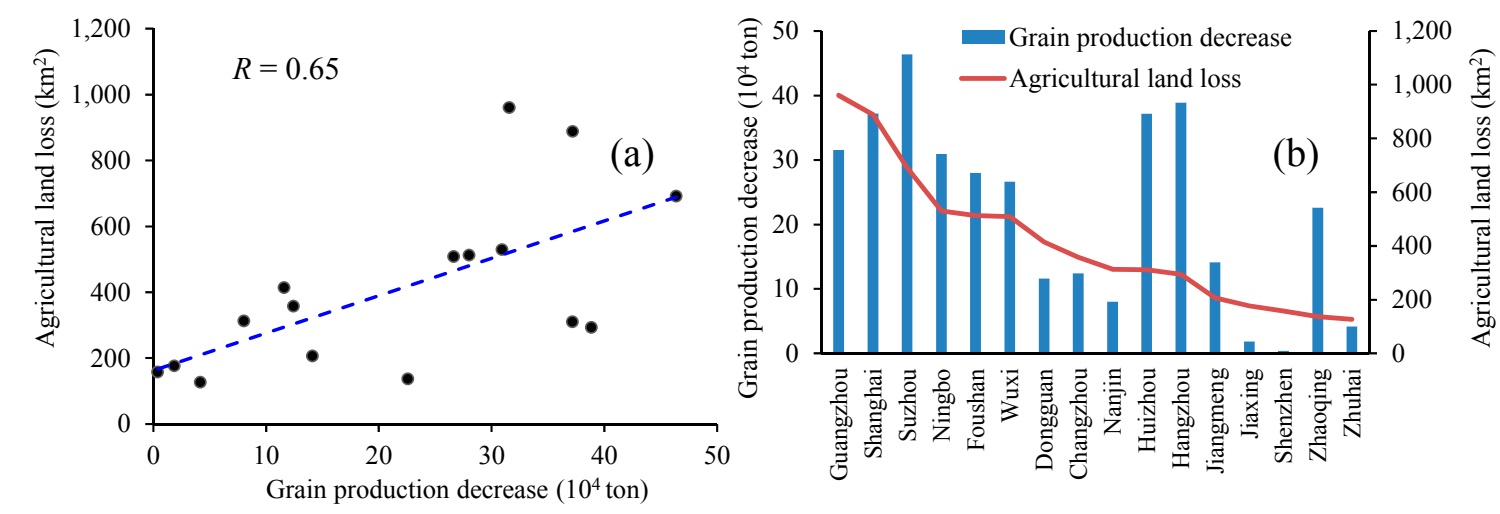

Figure 11. Relationship between urbanization-related agricultural land loss and grain production decrease in the typical cities. (a) Correlation relationship; (b) trend relationship.

\subsection{Strategies for Mitigating Urbanization-Related Agricultural Land Loss}

There is a pressing need for China to relieve urbanization-related agricultural land loss, but not hinder the growth of the economy. Key measures to solve current land problems include rational urban planning and strict agricultural land protection. Specific strategies were suggested as follows: (1) rationally control the direction and speed of urbanization to avoid blind urban sprawl; (2) increase efficiency of urban land use and adjust land use structure to optimize the allocation of urban land resources; (3) strictly implement the protection policies on the quantity and quality of agricultural land; and (4) effectively conduct land development, consolidation, and reclamation.

Due to different areas with great disparities of urban expansion and economic development, it is imperative to implement differentiated strategies to alleviate urbanization-related agricultural land loss. For the eastern region, more attention should be paid to the protection of high-quality agricultural land and improvement efficiency of urban land use. Because agricultural land loss was mainly from high-quality agricultural land in the eastern region, it is necessary to strictly protect the remaining high-quality agricultural land, and rationally implement land development, consolidation, and reclamation to supplement the shortage of agricultural land. In addition, the increased efficiency of urban land use could use its limited land resources more effectively, and slow down the rapid urban expansion. As the central and western regions are the important food producing areas in China, more attention should be paid to the strict protection policies on agricultural land, especially cropland. However, because the central and western regions are at an early stage of urbanization, it would be impossible to completely relieve agricultural land loss in the short term. It is probably more feasible in a short period to: (1) increase the efficiency of urban land use on the basis of intensive land use; (2) harmonize agricultural land demands among various urban organizations; and (3) solve conflicts of agricultural land demand among various urban departments. For the six metropolitan areas already at a relatively high development stage of urbanization, rational urban land use is an urgent task to relieve agricultural land loss. For example, high-tech manufacturing, financial, service, and Internet industries with low urban land demands should be vigorously supported, while highly land-demanding industries should be shut down or relocated to other places. Corresponding policies should be made in time to benefit agricultural land protection. For instance, tax and loan preference and financial subsidies could be given to companies with low land demands. Meanwhile, extra taxations should be imposed on industries with land waste, low land output efficiency, and poor land use structure. The six metropolitan areas also need to rationally guide the flow of population to avoid the blind expansion of urban living space due to a high intensity of population.

\subsection{Limitations and Future Perspectives}

There are a few limitations that need to be improved in future studies. For example, some natural features could be excluded from urban areas, but the NFS method falls short of eliminating 
all the "blooming" natural features because the NSL data have a relatively coarse spatial resolution. The accuracy of mapping agricultural land loss also largely depends on the NLC data. Although the accuracy of the NLC data has been proven, mismatches between the estimated urban areas and NLC data still exist, resulting in some errors when evaluating agricultural land loss caused by urban expansion. We will analyze the relationship between urbanization and agricultural land using time series nighttime light data and NLC data to investigate the direction and trend of urbanization-related agricultural land loss in China.

\section{Conclusions}

Most studies on the spatial pattern of urbanization-related agricultural land loss in China have been conducted at the local scale. Few have considered it in a timely manner, especially at the national scale. Based on the integration of the NSL, NDVI, water body, and NLC data, this study examined urban expansion and agricultural land loss in China at multiple scales from 2001 to 2013. Urban expansion was firstly mapped using the NSL, NDVI, and water body data. The urbanization-related agricultural land loss was then evaluated from a national scale to regional and metropolitan scales. The validation results demonstrated that the NFS method could be effective and accurate for mapping urban expansion. The urban expansion was mainly identified in the eastern region, $\mathrm{SNH}, \mathrm{BTT}$, and PRD. The widespread urban expansion has caused a total loss of agricultural land of 33,080 km² in China from 2001 to 2013. At a regional scale, the high level of agricultural land loss was concentrated in the eastern region. At a metropolitan scale, agricultural land loss was mainly found in the SNH, PRD, and BTT.

Because significant urbanization-related agricultural land loss has a positive correlation with grain production decrease in some developed areas, there is a pressing need for China to relieve urbanization-related agricultural land loss. The relief strategies for China should mainly focus on rational urban planning and strict agricultural land protection. For the eastern region, more attention should be paid to improving the efficiency of urban land use and enhancing the protection of high quality cultivated land, while the central and western regions should incorporate and harmonize agricultural land demands among various urban departments. Rationalizing urban land use is also an urgent task to relieve agricultural land loss in the six metropolitan areas.

Supplementary Materials: The following are available online at www.mdpi.com/2071-1050/8/8/790/s1, Figure S1: Identifying the transition zones and central urban areas from the topographic maps, Figure S2: Extracting the marginal urban areas from mixed maps, Figure S3: Mapping primary and reclassified urban maps.

Acknowledgments: This work is supported by the National Natural Science Foundation of China (No. 41471449), the Natural Science Foundation of Shanghai (No. 14ZR1412200), the Innovation Program of Shanghai Municipal Education Commission (No. 15ZZ026), the Fundamental Research Funds for the Central Universities of China, and the China Scholarship Council (No. 201406140007). The authors also wish to thank their colleague Susan Cuddy for her helpful suggestions.

Author Contributions: Yun Chen, Bailang Yu, and Jianping Wu conceived and supervised the research topic. Kaifang Shi and Bailang Yu proposed the methods. Kaifang Shi, Linyi Li, Chang Huang, Rui Liu, and Zuoqi Chen processed the data. Kaifang Shi, Yun Chen, and Tingbao Xu analyzed the results and wrote the paper.

Conflicts of Interest: The authors declare no conflict of interest.

\section{References}

1. Lambin, E.F.; Turner, B.L.; Geist, H.J.; Agbola, S.B.; Angelsen, A.; Bruce, J.W.; Coomes, O.T.; Dirzo, R.; Fischer, G.; Folke, C. The causes of land-use and land-cover change: Moving beyond the myths. Glob. Environ. Chang. 2001, 11, 261-269. [CrossRef]

2. Kraemer, R.; Prishchepov, A.V.; Müller, D.; Kuemmerle, T.; Radeloff, V.C.; Dara, A.; Terekhov, A.; Frühauf, M. Long-term agricultural land-cover change and potential for cropland expansion in the former Virgin Lands area of Kazakhstan. Environ. Res. Lett. 2015. [CrossRef] 
3. Gutzler, C.; Helming, K.; Balla, D.; Dannowski, R.; Deumlich, D.; Glemnitz, M.; Knierim, A.; Mirschel, W.; Nendel, C.; Paul, C. Agricultural land use changes-A scenario-based sustainability impact assessment for Brandenburg, Germany. Ecol. Indic. 2015, 48, 505-517. [CrossRef]

4. Barati, A.; Asadi, A.; Kalantari, K.; Azadi, H.; Witlox, F. Agricultural land conversion in Northwest Iran. Int. J. Environ. Res. 2015, 9, 281-290.

5. Del Mar López, T.; Aide, T.M.; Thomlinson, J.R. Urban expansion and the loss of prime agricultural lands in Puerto Rico. Ambio J. Hum. Environ. 2001, 30, 49-54. [CrossRef]

6. Pandey, B.; Seto, K.C. Urbanization and agricultural land loss in India: Comparing satellite estimates with census data. J. Environ. Manag. 2015, 148, 53-66. [CrossRef] [PubMed]

7. Pribadi, D.O.; Pauleit, S. The dynamics of peri-urban agriculture during rapid urbanization of Jabodetabek Metropolitan Area. Land Use Pol. 2015, 48, 13-24. [CrossRef]

8. Thapa, R.B.; Murayama, Y. Examining spatiotemporal urbanization patterns in Kathmandu Valley, Nepal: Remote sensing and spatial metrics approaches. Remote Sens. 2009, 1, 534-556. [CrossRef]

9. Zhong, T.; Huang, X.; Zhang, X.; Wang, K. Temporal and spatial variability of agricultural land loss in relation to policy and accessibility in a low hilly region of southeast China. Land Use Pol. 2011, 28, 762-769.

10. Richards, P.D.; Walker, R.T.; Arima, E.Y. Spatially complex land change: The Indirect effect of Brazil's agricultural sector on land use in Amazonia. Glob. Environ. Chang. 2014, 29, 1-9. [CrossRef] [PubMed]

11. Bai, X.; Shi, P.; Liu, Y. Society: Realizing China's urban dream. Nature 2014, 509, 158-160. [CrossRef] [PubMed]

12. Zhou, L.; Dickinson, R.E.; Tian, Y.; Fang, J.; Li, Q.; Kaufmann, R.K.; Tucker, C.J.; Myneni, R.B. Evidence for a significant urbanization effect on climate in China. Proc. Natl. Acad. Sci. USA 2004, 101, 9540-9544. [CrossRef] [PubMed]

13. He, C.; Liu, Z.; Tian, J.; Ma, Q. Urban expansion dynamics and natural habitat loss in China: A multiscale landscape perspective. Glob. Chang. Biol. 2014, 20, 2886-2902. [CrossRef] [PubMed]

14. Jiang, L.; Deng, X.; Seto, K.C. The impact of urban expansion on agricultural land use intensity in China. Land Use Pol. 2013, 35, 33-39. [CrossRef]

15. Deng, X.; Huang, J.; Rozelle, S.; Zhang, J.; Li, Z. Impact of urbanization on cultivated land changes in China. Land Use Pol. 2015, 45, 1-7. [CrossRef]

16. Tan, M.; Li, X.; Xie, H.; Lu, C. Urban land expansion and arable land loss in China-A case study of Beijing-Tianjin-Hebei region. Land Use Pol. 2005, 22, 187-196. [CrossRef]

17. Liang, C.; Penghui, J.; Manchun, L.; Liyan, W.; Yuan, G.; Yuzhe, P.; Nan, X.; Yuewei, D.; Qiuhao, H. Farmland protection policies and rapid urbanization in China: A case study for Changzhou City. Land Use Pol. 2015, 48, 552-566. [CrossRef]

18. Ma, L.; Guo, J.; Velthof, G.L.; Li, Y.; Chen, Q.; Ma, W.; Oenema, O.; Zhang, F. Impacts of urban expansion on nitrogen and phosphorus flows in the food system of Beijing from 1978 to 2008. Glob. Environ. Chang. 2014, 28, 192-204. [CrossRef]

19. Fazal, S. Urban expansion and loss of agricultural land-A GIS based study of Saharanpur City, India. Environ. Urban. 2000, 12, 133-149. [CrossRef]

20. Cao, X.; Chen, J.; Imura, H.; Higashi, O. A SVM-based method to extract urban areas from DMSP-OLS and SPOT VGT data. Remote Sens. Environ. 2009, 113, 2205-2209. [CrossRef]

21. Ma, Q.; He, C.; Wu, J.; Liu, Z.; Zhang, Q.; Sun, Z. Quantifying spatiotemporal patterns of urban impervious surfaces in China: An improved assessment using nighttime light data. Landsc. Urban Plan. 2014, 130, $36-49$. [CrossRef]

22. Liu, J.; Liu, M.; Tian, H.; Zhuang, D.; Zhang, Z.; Zhang, W.; Tang, X.; Deng, X. Spatial and temporal patterns of China's cropland during 1990-2000: An analysis based on Landsat TM data. Remote Sens. Environ. 2005, 98, 442-456. [CrossRef]

23. Liu, J.; Zhang, Z.; Xu, X.; Kuang, W.; Zhou, W.; Zhang, S.; Li, R.; Yan, C.; Yu, D.; Wu, S. Spatial patterns and driving forces of land use change in China during the early 21st century. J. Geogr. Sci. 2010, 20, 483-494. [CrossRef]

24. Shi, K.; Chen, Y.; Yu, B.; Xu, T.; Chen, Z.; Liu, R.; Li, L.; Wu, J. Modeling spatiotemporal $\mathrm{CO}_{2}$ (carbon dioxide) emission dynamics in China from DMSP-OLS nighttime stable light data using panel data analysis. Appl. Energy 2016, 168, 523-533. [CrossRef] 
25. Xie, Y.; Weng, Q. Detecting urban-scale dynamics of electricity consumption at Chinese cities using time-series DMSP-OLS (Defense Meteorological Satellite Program-Operational Linescan System) nighttime light imageries. Energy 2016, 100, 177-189. [CrossRef]

26. Elvidge, C.D.; Ziskin, D.; Baugh, K.E.; Tuttle, B.T.; Ghosh, T.; Pack, D.W.; Erwin, E.H.; Zhizhin, M. A fifteen year record of global natural gas flaring derived from satellite data. Energies 2009, 2, 595-622. [CrossRef]

27. Wu, J.; He, S.; Peng, J.; Li, W.; Zhong, X. Intercalibration of DMSP-OLS night-time light data by the invariant region method. Int. J. Remote Sens. 2013, 34, 7356-7368. [CrossRef]

28. Liu, Z.; He, C.; Zhang, Q.; Huang, Q.; Yang, Y. Extracting the dynamics of urban expansion in China using DMSP-OLS nighttime light data from 1992 to 2008. Landsc. Urban Plan. 2012, 106, 62-72. [CrossRef]

29. Pandey, B.; Joshi, P.; Seto, K.C. Monitoring urbanization dynamics in India using DMSP/OLS night time lights and SPOT-VGT data. Int. J. Appl. Earth Observ. Geoinf. 2013, 23, 49-61. [CrossRef]

30. Shi, K.; Huang, C.; Yu, B.; Yin, B.; Huang, Y.; Wu, J. Evaluation of NPP-VIIRS night-time light composite data for extracting built-up urban areas. Remote Sens. Lett. 2014, 5, 358-366. [CrossRef]

31. Elvidge, C.D.; Baugh, K.E.; Dietz, J.B.; Bland, T.; Sutton, P.C.; Kroehl, H.W. Radiance calibration of DMSP-OLS low-light imaging data of human settlements. Remote Sens. Environ. 1999, 68, 77-88. [CrossRef]

32. Small, C.; Pozzi, F.; Elvidge, C.D. Spatial analysis of global urban extent from DMSP-OLS night lights. Remote Sens. Environ. 2005, 96, 277-291. [CrossRef]

33. Elvidge, C.D.; Tuttle, B.T.; Sutton, P.C.; Baugh, K.E.; Howard, A.T.; Milesi, C.; Bhaduri, B.; Nemani, R. Global distribution and density of constructed impervious surfaces. Sensors 2007, 7, 1962-1979. [CrossRef]

34. Sutton, P.C. A scale-adjusted measure of "urban sprawl" using nighttime satellite imagery. Remote Sens. Environ. 2003, 86, 353-369. [CrossRef]

35. Su, Y.; Chen, X.; Wang, C.; Zhang, H.; Liao, J.; Ye, Y.; Wang, C. A new method for extracting built-up urban areas using DMSP-OLS nighttime stable lights: A case study in the Pearl River Delta, southern China. GISci. Remote Sens. 2015, 52, 218-238. [CrossRef]

36. Su, Y.; Chen, X.; Ye, Y.; Wu, Q.; Zhang, H.O.; Huang, N.; Kuang, Y. The characteristics and mechanisms of carbon emissions from energy consumption in China using DMSP/OLS night light imageries. Acta Geogr. Sin. 2013, 68, 1513-1526.

37. Yang, Y.; He, C.; Zhang, Q.; Han, L.; Du, S. Timely and accurate national-scale mapping of urban land in China using Defense Meteorological Satellite Program's Operational Linescan System nighttime stable light data. J. Appl. Remote Sens. 2013, 7, 1-18. [CrossRef]

38. Huang, Q.; He, C.; Gao, B.; Yang, Y.; Liu, Z.; Zhao, Y.; Dou, Y. Detecting the 20 year city-size dynamics in China with a rank clock approach and DMSP/OLS nighttime data. Landsc. Urban Plan. 2015, 137, 138-148. [CrossRef]

39. Zhang, Q.; Seto, K.C. Mapping urbanization dynamics at regional and global scales using multi-temporal DMSP/OLS nighttime light data. Remote Sens. Environ. 2011, 115, 2320-2329. [CrossRef]

40. The Land Use/Cover Classification Scheme (2006-2020) Developed by the Outline of the National Overall Planning on Land Use. Available online: http:/ /www.mlr.gov.cn/xwdt/jrxw/200810/t20081024_111040. htm (accessed on 10 August 2016). (In Chinese)

41. Ran, Y.; Li, X.; Lu, L. Evaluation of four remote sensing based land cover products over China. Int. J. Remote Sens. 2010, 31, 391-401. [CrossRef]

42. Angel, S.; Sheppard, S.; Civco, D.L.; Buckley, R.; Chabaeva, A.; Gitlin, L.; Kraley, A.; Parent, J.; Perlin, M. The Dynamics of Global Urban Expansion; World Bank, Transport and Urban Development Department: Washington, DC, USA, 2005.

43. Dadi, D.; Azadi, H.; Senbeta, F.; Abebe, K.; Taheri, F.; Stellmacher, T. Urban sprawl and its impacts on land use change in Central Ethiopia. Urban For. Urban Green. 2016, 16, 132-141. [CrossRef]

44. Sharma, R.; Joshi, P. Mapping environmental impacts of rapid urbanization in the National Capital Region of India using remote sensing inputs. Urban Clim. 2016, 15, 70-82. [CrossRef]

45. Dewan, A.M.; Yamaguchi, Y. Land use and land cover change in Greater Dhaka, Bangladesh: Using remote sensing to promote sustainable urbanization. Appl. Geogr. 2009, 29, 390-401. [CrossRef]

46. Chen, J. Rapid urbanization in China: A real challenge to soil protection and food security. Catena 2007, 69, 1-15. [CrossRef]

47. Qin, X.; Zhang, F.; Liu, C.; Yu, H.; Cao, B.; Tian, S.; Liao, Y.; Siddique, K.H. Wheat yield improvements in China: Past trends and future directions. Field Crop. Res. 2015, 177, 117-124. [CrossRef] 
48. Yan, T.; Wang, J.; Huang, J. Urbanization, agricultural water use, and regional and national crop production in China. Ecol. Model. 2015, 318, 226-235. [CrossRef]

49. Yi, F.; Sun, D.; Zhou, Y. Grain subsidy, liquidity constraints and food security-Impact of the grain subsidy program on the grain-sown areas in China. Food Policy 2015, 50, 114-124. [CrossRef]

(c) 2016 by the authors; licensee MDPI, Basel, Switzerland. This article is an open access article distributed under the terms and conditions of the Creative Commons Attribution (CC-BY) license (http:/ / creativecommons.org/licenses/by/4.0/). 